\title{
Gaddafi and Latin America
}

\author{
Jose Esteban Castro
}

Published online: 21 May 2011

(C) Springer Science+Business Media, LLC 2011

The late Argentinian writer Jorge Luis Borges once said that he never read a newspaper because he could not believe that something truly important can be known in $24 \mathrm{~h}$. Although taking Borges literally would not be advisable for social scientists trying to make sense of pressing current events, I cannot but recall his words while writing about such a fast moving target as the object of this article. In this regard, the reactions to the Libyan "crisis" in Latin America have been characterized by a wide range of positions and a heated debate, which is not possible to properly reproduce in a short essay. I have placed the emphasis on, broadly speaking, the reactions of the Latin American "left" to the events in Libya. An important reason for this is that a number of commentators have accused the "Latin American left", and the region more generally, of being silent about or even complicit with the atrocities committed by the Gaddafi regime in recent weeks. The mass media in Europe and the Americas have amplified this message, helping to create a perception that the Latin American left and indeed most Latin American countries would have adopted a generalized position of support for, or at best indifference about, the repression carried out by the Libyan dictatorship.

For instance, on 6 March 2011 the online Spanish business newspaper Libertad Digital published an article titled "the Latin American left backs Gaddafi". Similar headings appeared in different places, mostly but not only in conservative or right-wing publications, both in Europe and the Americas. This included an article on "the Arab revolution and the Latin American left" written by Joaquín

J. E. Castro $(\bowtie)$

School of Geography, Politics and Sociology,

Newcastle University,

5th Floor Claremont Bridge Building,

NE1 7RU, Newcastle upon Tyne, UK

e-mail: j.e.castro@newcastle.ac.uk
Villalobos, a former guerrilla commander from El Salvador, in the Spanish newspaper El País (22 February 2011). Not everyone has joined this blanket accusation against "the Latin American left", and careful analysts have raised more specific questions such as "how can Latin America's 'revolutionary' leaders support Gaddafi?" (The Guardian, 28 February 2011). This echoed a number of previous interventions that put the finger on the positions taken by the countries of the ALBA [Bolivarian Alliance for the Americas, headed by Bolivia, Cuba, Ecuador, Nicaragua, and Venezuela] on the matter. For instance, former Mexican foreign minister Jorge Castañeda wrote that "the left of the Latin American ALBA shows solidarity with Gaddafi" (Reforma, Mexico, 24 February 2011), adding his voice to a chorus of commentators sharing similar views and circumscribing the accusation to this smaller group of countries. More broadly, others like the conservative Spanish newspaper $A B C$ have accused Latin American institutions like MERCOSUR [Southern Common Market] and UNASUR [Union of South American Nations] either of being silent about the repression of the Libyan population by the Gaddafi regime or of reducing it to a national problem that is better left to the Libyans ( $A B C, 11$ March 2011).

However, a closer review of the Latin American debate on the Libyan situation shows a much more textured landscape. For the sake of clarity, it is vital to establish a difference between a) the official positions taken by Latin American governments in relation to Gaddafi's repression of Libyan rebels, b) their positions regarding military intervention in Libya, including UN Security Council Resolution 1973 authorizing it, and c) the ongoing debates of Latin American intellectuals and social and political movements. Also, it is important to clarify that despite the blanket label of "Latin American left" used by the critics to refer for instance to the ALBA countries, the left-wing 
credentials of these governments have been seriously questioned in the region. At most, some would say, you could talk about "progressive" governments that are implementing restricted redistributive policies, largely populist, which have reversed the pattern of increasing inequality characterizing the 1980s and 1990s. However, few would argue that the so-called "left-wing" governments of Latin America, including ALBA countries, have a strong and comprehensive commitment towards the principles historically defended by the left. For instance, with the exception of Argentina, "left-wing" governments have not showed a real commitment to prosecute those responsible for the crimes against humanity committed during the dictatorships of the 1960s-1980s. In fact, it can be argued that these countries have been more concerned with the consolidation of national capitalist autonomies rather than with building the bases for a socialist project for the $21^{\text {st }}$ century, despite the rhetoric of President Chávez and others on this issue. This is not the place to explore the pros and cons of such arguments, but I only want to highlight some fundamental problems facing those commentators launching blanket accusations against the straw man of the Latin American left and its reaction to Gaddafi's crimes.

The declarations of former revolutionary leaders and current presidents of the ALBA countries gave ground for the accusations launched against "the left". Perhaps the most notorious case has been that of Nicaraguan President Daniel Ortega who reportedly pledged full support for Gaddafi from his government, the Sandinista Front, and the people of his country. The governments of President Hugo Chávez in Venezuela and Rafael Correa in Ecuador also came short of condemning Gaddafi's repression of his own people. Correa went further and reacted to the decision of the International Court of Human Rights to prosecute Gaddafi and, interpreting - it has to be said - a widespread concern among Latin Americans, reportedly stated that "before condemning any country as terrorist, the International Court should prosecute [former US President] Bush" in reference to the massive human rights violations connected with the USled wars in Iraq and Afghanistan. An official statement of the Cuban government declared its preoccupation with the loss of human life and the harm caused to innocent civilians everywhere in the world, including Libya. However, former Cuban President Fidel Castro and official representatives of the Cuban government questioned the accuracy and veracity of Western media reports about Gaddafi's repression, claiming that it was part of a campaign of manipulation and misinformation to justify military intervention in Libya. The South American TV channel TELESUR, based in Caracas (but sponsored by the governments of Argentina, Bolivia, Cuba, Ecuador, Nicaragua, Uruguay and Venezuela) became under heavy attack for its coverage of the Libyan uprising. While TELESUR's reporting on the Egyptian and Tunisian revolutions had been extensive and the channel had celebrated the successful rebellions in these countries as victories of the people, the situation in Libya received much less attention and Gaddafi's repressive response was played down or even went unreported for several days. Unfortunately this may have severely damaged TELESUR's reputation as an objective source of information that provides a counterbalance to the Western-based media monopolies that have historically controlled information flows in Latin America. Inevitably, the well-known historical relationships between the leaders of the ALBA countries and Gaddafi were pointed out by many as a key reason for the official positions adopted by these countries, which ranged from ambiguity to full support for the Libyan dictator, as well as for TELESUR's biased coverage of the events. We come back this later.

However, it is important to examine the official reactions to Gaddafi's crimes in closer detail. Among the countries that were first to react and condemn the Gaddafi regime for its atrocities there are some whose right-leaning governments are themselves subject to serious allegations of systematic human rights violations against their own citizens, such as Colombia, Mexico and Peru (this country immediately broke diplomatic relations with Libya). Even the Honduran government that emerged from a violent military coup against democratically elected President Manuel Zelaya in 2009 also condemned Gaddafi's repression and expressed solidarity with the Libyan rebels, which has risen more than a few eyebrows. Other countries like Chile or Costa Rica, also governed by right-ofcentre political parties, rapidly expressed open condemnation of Gaddafi's repression too. However, left-leaning governments such as those from Argentina, Bolivia, Brazil, Paraguay, and Uruguay (that includes the four core MERCOSUR countries) also made strong statements against Gaddafi's atrocities. For instance, the Argentinean government expressed "deep preoccupation for the grave human rights violations in Libya" and supported the call for a special meeting of the UN Human Rights Council on 25 February 2011 to discuss the situation and avoid a "human rights vacuum" in that country.

In conclusion, it would be fair to say that the official responses of the vast majority of Latin American countries have expressed a clear position against the human rights violations of the Libyan regime. Overall, the countries governed by left-leaning or progressive parties have made explicit their rejection of Gaddafi's violence against civilians. However, there has been a much clearer divide between Latin American countries in relation to Western-led intervention (particularly military) in Libya, which most left-of-centre governments have firmly rejected. To this we turn next.

The Latin American countries governed by right-leaning governments have openly supported military intervention in Libya. This includes Colombia, a country currently occupying a temporal position in the UN Security Council, which voted in favor of Resolution 1973 authorizing the 
establishment of a no-fly-zone and leaving open the possibility of further military action. Although Brazil abstained from voting Resolution 1973 like China, Russia, Germany, and India, which in fact helped the case for military action, most left-of-centre governments in Latin America rejected military intervention. All these countries have openly criticized the military attacks on Libya launched by the forces led by France, Britain and the US under Resolution 1973. Prior to the passing of the resolution on 17 March, the ALBA countries had taken the lead in opposing the possibility of a military intervention in Libya. For instance, the Cuban representative at the UN Human Rights Council, Ambassador Rodolfo Reyes, argued for a "peaceful and sovereign solution without any foreign interference or intervention in order to guarantee the integrity of the Libyan Nation". More informally, former Cuban President Fidel Castro had pointed at the "cynicism" of the West in using the cover of a humanitarian intervention to actually wage a war to gain control of Libyan resources, particularly oil and its geopolitical strategic position in North Africa. Also, President Chavez offered Gaddafi the creation of a "Peace Committee" that would include friendly countries and the Arab League to mediate the situation and stop the possibility of a Western-led invasion of the country. In this connection, his foreign minister Nicolás Maduro stated that Western attempts to isolate Gaddafi and provide support for the rebels were setting the scene for a full-fledged imperial invasion of Libya.

In order to better understand the non-interventionist position taken by most Latin American countries it has to be contextualized. The long history of Western, and particularly US intervention in Latin America, plays a significant role in the reactions observed. Recent military interventions in the region like the failed military coup against President Chavez in 2002 with strong US participation or the successful military coup against Honduran President Zelaya in 2009, also with some degree of US involvement, are clear examples but not the only ones. Bolivia and Paraguay have also suffered similar situations in the last few years. The also recent establishment of US military bases in Colombian territory and the recommissioning of the US IV Fleet to patrol the seas of Latin America, one of the last decisions taken by former President Bush before leaving office that has not been reversed by President Obama, have caused much concern in the region, clearly but not only among left-of-centre governments. In specific relation to the Libyan case, inevitably the ties forged between the young revolutionary Gaddafi of 1979 and his Latin American counterparts fighting against US-backed military dictatorships across the region at the time constitute a legacy with lasting effects on the relationships between Gaddafi and these countries, notably Cuba and Nicaragua. These ties were reinforced in recent years through the attempts made by Latin American countries to reduce the economic, technological and political influence of the US in the region by developing strategic alliances with world powers like China, India, Russia, among others, and also establishing stronger SouthSouth interactions, particularly with Africa and Asia, with Libya becoming an important partner in geo-political terms. Needless to say, as discussed in other articles in this issue, the establishment of stronger links with Gaddafi in recent years has not been the preserve of the Latin American left, and Western European countries, notoriously Britain, France, Germany and Italy, took the lead in making the Libyan dictator an accepted member of the international community since 2004. In the process, Gaddafi became a major investor in Europe, secured strategic oil exports to the continent, and became an ally in the "war against terror" and in the control of migration flows to Europe from African countries. At the same time, he also pledged to support and even lead a new wave of revolutionary efforts in Africa and Latin America.

Going back to our main point, left-wing intellectuals and social and political movements have produced excellent analyses (see a selection of sources in the reading list) of the implications that the reactions of the Latin American left to the Libyan crisis has for the future of emancipatory social and political movements. Despite the nuances and differences between these analyses, it is possible to identify some broad common patterns that can be summarized in three main positions for the sake of brevity and clarity.

The first position, that could be termed the "grassroots position", assumes that the Libyan uprising is a genuine revolt of the people against Gaddafi's dictatorship (see selection of articles in The Worker's Truth and other sources in the reading list). For these actors, Gaddafi has become an ally of the imperialist countries, heavily investing in some economies (e.g. Italy), helping Europe to control the mass migration of Africans to the continent, even acting as an ally in the anti-terror war. They argue that the Latin American left (workers, social and political movements, etc.) should support the rebels against Gaddafi but oppose a UN-NATO military intervention, which would only respond to the strategic interests of the West: securing access to Libyan oil and recovering a military position in North Africa now that their strategically positioned puppet regimes in Egypt and Tunisia have fallen. These actors argue that the support that some Latin American governments, particularly Cuba, Nicaragua and Venezuela, gave to Gaddafi is shameful. These countries have even denied Gaddafi's bombardment of the Libyan people. They claim that the Venezuelan initiative to create a "Peace Committee" for Libya is also a project for military intervention like that of the imperialist powers. According to them, the only alternative available for grassroots left-wing movements in Latin America is to support the Libyan rebels against 
Gaddafi and protect them from the imperialist counterrevolution in process under the guise of a humanitarian intervention. They believe that the real objective of the Western powers is not to introduce a genuinely democratic process in Libya and the Arab countries but to halt their military and political losses in North Africa and the Middle East and avoid the spread of revolutionary transformations to other countries, especially Saudi Arabia or Jordan.

The second position can perhaps be called the "progressive democratization" argument (see, for instance, Astarita 2011). It has strong commonalities with the arguments of the first position, particularly in accepting the genuine character of the rebellion as an emancipatory struggle against Gaddafi's dictatorship and denouncing the open or tacit defense of Gaddafi by sections of the Latin American left. However, this position rejects the argument that an intervention in Libya would necessarily be the result of an imperialist project. On the contrary, these actors argue that the record of emancipatory struggles shows that support from capitalist countries in specific historical circumstances does not necessarily mean subordination to capitalist interests on the part of the revolutionaries. Notorious examples would be the tacit support given to Fidel Castro by the US government in the early stages of the Cuban Revolution, or the support that Latin American left-wing movements fighting the dictatorships of the 1960s-1990s received from capitalist countries, particularly from Europe. For the actors defending this position, the revolution that would emerge from an UN-led intervention in Libya would obviously not be socialist, but after all this is not what the rebels are fighting for. It would rather be a bourgeois revolution that may introduce some democratic rights like freedom of speech, the right to fair judicial procedures, or the right to form political parties, all of which are currently denied to the Libyan people. It would be criminal, these actors argue, to oppose an international intervention to stop Gaddafi's repression of his own people that could also bring about some limited but nevertheless significant emancipatory freedoms within the limits of capitalist democracy. Consequently these actors accuse the, broadly speaking, "nationalist left" that rejects UN Resolution 1973 as an attack on Libya's national sovereignty of treason against the fundamental principles of the left and of tacitly or explicitly supporting the dictatorship of Gaddafi rather than the Libyan people fighting for freedom.

Finally, the third position, that can be named "internationalistrevolutionary" (see for instance, Alba Rico and Allende 2011), also shares a number of assumptions with the others. It also denounces Gaddafi's dictatorship and rejects the blanket accusations against "imperialist countries" as being responsible for the Libyan crisis. The actors in this position strongly criticize the open defense of the dictator made by some Latin American countries like Nicaragua and call for support for the Arab revolutionaries, who are not puppets of a Western conspiracy but are rather genuinely fighting for democracy in their own terms. However, while the actors of the first two positions show a distinctive distrust for the state, and most notoriously for the positions taken by Latin American governments that are notionally "left-wing", the actors in the third position place much more emphasis on the role that national governments can play in the process. These actors claim that under the leadership of the ALBA countries Latin America must take a firm position rejecting the intervention of Western powers in Libya but at the same time taking an active role in supporting the revolutionary process in the whole of North Africa and the Middle East. Failing to do so would probably mean the end of the current wave of global emancipatory processes, and the loss of a historical opportunity to change the power balance at the international level and deepening the process of revolutionary change. These actors are careful to point out that the leading ALBA countries, particularly Cuba and Venezuela, have the historical responsibility of avoiding or correcting the mistakes made in relation to Gaddafi's crimes, and should explicitly condemn the dictator and support the Arab rebels. Failing to support the Arab revolutionaries would give further ground to the accusations slashed at the left, and particularly the ALBA countries, while also allowing the Western powers to regain the initiative and occupy the moral high ground that is been emptied by the mistakes or inaction of the Latin American left. Importantly, these actors argue that the understandable "state reasons" and "realpolitik" that place limits on what national governments can do should not be used to justify supporting a criminal dictator like Gaddafi and abandon the rebels to their own destiny. It would amount to treason of the Bolivarian ideals and of the revolutionary tradition of Latin America more generally.

Summing up, an examination of the on-going Latin American debates about the Libyan uprising bring out a highly diverse and textured intellectual and political landscape, much more complex than the picture portrayed by some commentators and reproduced and amplified by the European and American mass media. Leaving aside the argument about the degree of consistency of current Latin American governments with left-wing principles and ideals, it becomes clear that the vast majority of countries have strongly reacted against Gaddafi's criminal repression of the Libyan people. However, the most heated debates concern the "what to be done", and particularly in relation to the Western-led initiatives for military intervention. While the history of Latin America partly explains the strong defence of the principle of non-intervention in sovereign affairs made by most countries, the debates within the left-which is also taking place inside the governments of the core ALBA countries-, cast light on the lack of monolithic positions or agreements within a notional "Latin American left". Surely Jorge Luis Borges was right after all in some respects, but an in depth 
exploration of the current debates suggests that some truly important things can also be learnt in the short term. Hopefully, this learning process may help the cause of those fighting for their freedom in Libya and elsewhere.

\section{Further Reading}

Alba Rico, S. and A. Allende. 2011. "Libya: an analysis from the left. From the Arab "world to Latin America", Rebelión, Cuba, 25 February 2011, (accessed in March 2011: http://www.rebelion.org/).

"Arab Revolt", collection of articles on the 2011 Arab uprisings, Carta Maior, Brazil (accessed in March 2011: www.cartamaior.com.br).

Astarita, R. 2011. "The left and Libya", 9 March 2011 (accessed in March 2011: http://www.aporrea.org/).
Articles on the Libyan uprising, Rebelión, Cuba (accessed in March 2011: http://www.rebelion.org/)

Articles on the Libyan uprising, Aporrea.org: Popular Communication for the Construction of 21st Century Socialism, Venezuela, (accessed in March 2011: http://www.aporrea.org/).

Boron, A. 2011. "What to do in Libya? A Latin American perspective", Rebelión, Cuba, 10 March 2011(accessed in March 2011: http:// www.rebelion.org/).

"Down Gaddafi. No to imperialist intervention", collection of articles on Libya's uprisings, La Verdad Obrera (The Worker's Truth), Socialist Workers' Party, Buenos Aires, Argentina (accessed in March 2011: www.pts.org.ar).

Jose Esteban Castro is Professor of Sociology, Newcastle University, United Kingdom. 